\title{
Feeding of Different Categories of Fish, their Nutritional Requirements and Implication of Various Techniques in Fish Culture - A Review
}

\author{
Prabhjot Kaur Sidhu* and Anant Simran Singh
}

Khalsa College of Veterinary and Animal Sciences, Amritsar-143001, Punjab, India

*Corresponding author

Keywords

Fish,

Nanotechnology,

Feed

Article Info

Accepted:

22 December 2019

Available Online:

20 January 2020

\section{A B S T R A C T}

Aqua cultural production is a major industry in many countries, and it will continue to grow as the demand for fisheries products increases and the supply from natural sources decreases. Good nutrition in animal production systems is essential to economical production of a healthy, high-quality product. In fish farming (aquaculture), nutrition is critical because feed typically represents approximately 50 percent of the variable production cost. Fish nutrition has advanced dramatically in recent years with the development of new, balanced commercial diets that promote optimal fish growth and health. The development of new species-specific diet formulations supports the aquaculture industry as it expands to satisfy increasing demand for affordable, safe, high-quality fish and seafood products. Article provides a general overview of the wide variety of nanomaterials and technologies in fish culture that offer significant promising role for water recovery.

\section{Introduction}

Rearing of fishes in tanks is being practiced in India since as early as 350 B.C making it one of the oldest food based Industry however it apparently became more popular in later years. Fishing industry in India is more popular in coastal states including Bengal, Orissa and Andhra Pradesh as compared to other states and Punjab and is a source of livelihood for over 14 million people. Talking about the date around 11, 34,948 tonnes of seafood worth 5.78 bilion US\$ $(37,870.90$ crore) was exported in 2016-17, of which frozen shrimp was top item to be exported.

On a global scale, cultured fish production has doubled from 1990 to 1996, reaching 26 million ton, and output could reach 39 million ton by 2010 (Radhakrishna, 2002).

Though world fish capture has reached a plateau at approximately 94 million tons (FAO, 2007) yet most recent estimates suggest that 52 percent of marine stocks are fully exploited, 17 percent are overexploited and 7 percent are totally depleted (FAO, 
2005a) while human population and demand has increased greatly in current years leading to great pressure on global aquaculture to bridge gap between supply and demand of fishes. According to (FAO, 2018) growing share of fish production is expected to be destined for human consumption (around 90 percent). The driving force behind this increase will be a combination of rising incomes and urbanization, linked with the expansion of fish production and improved distribution channels. In per capita terms, world fish consumption is projected to reach $21.5 \mathrm{~kg}$ in 2030, up from $20.3 \mathrm{~kg}$ in 2016. Fish nutrition has shown a boom in recent years due to increased demand and with development of new technologies like nano diets which have leaded to increased fish growth and health leading to manufacture affordable, safe and high quality fish and sea food products.

\section{Feeding behavior according to different categories of fish}

Aquaculture deals with farming of aquatic animals in inland or coastal areas, which involves a sole ownership to cultivate the stock (FAO, 2009). Fish being highly nutritive in nature, it provides a large amount of protein and oil in both basic and reduced (fish meal) form which is used for animal culture. Its unique amino acid profile and high digestibility makes it one of the essential component of modern day animal farming. Tacon et al., 2006 divided aquaculture into four broad categories based upon the relative position of the animals cultured in the trophic hierarchy and thus the fishmeal and fish oil in their diets.

Carnivorous finfish: included fishes with high protein requirements which should be mostly from animal sources. This group includes the salmonids, as well as many marine and freshwater species such as seabass, seabream, eels, amberjack, groupers and snakeheads. 20$40 \%$ of fishmeal is required these species require from 20 to 40 percent fishmeal in their diets.

Herbivorous/omnivorous finfish: depends upon lower protein requirement which can be derived from either plant or animal sources and includes fishes like common carp, grass carp, other cyprinids, catfish and milkfish, all of which require around 5 percent fishmeal content in their feeds.

Omnivorous/scavenging crustaceans: they require between 15 and 25 percent fishmeal in their diets and includes the marine shrimps, freshwater prawns, crabs and crayfishes.

Filter-feeding finfish: these species do not need supplementary feed and just thrives on phyto- and zooplankton for their dietary requirements. They include silver carp, bighead carp, catla and rohu.

Feeding behavior of fishes is mainly effected by factors like stocking density, sex ratio, biological and physiological status, however limited investigation can lead to conflict between and within species. Some of the rhythms are controlled by endogenous clock mechanisms, but environmental factors, such as day length or temperature, may either control others or act as time setters or synchronizers (Madrid et al., 2001).

Understanding of the physiologic rhythms in farmed fish can help to provide useful information about the selection of proper times for feeding fish to maximize growth, improve feed efficiency, and reduce feed wastage and fecal output to minimize the environmental impacts of aquaculture. The three marked feeding rhythms that affect food consumption in fish are diel(daily), annual (seasonal), and tidal (lunar) rhythms. Most fish in culture systems have diel feeding 
rhythms whereby they are either diurnal feeders (eat during the day) or nocturnal feeders (eat at night).Biotic factors(such as threat of predation) and abiotic factors (such as lighting conditions) affects changes in many fishes on the feeding pattern (Daan $\mathrm{S}$ 1981 and Bougard et al., 1992). On the basis of culture system used, feeds and feeding of fish depend upon: extensive, semi intensive or intensive system. In extensive and semi intensive, fish derive all or a substantial part of their nutrients from natural food organisms in culture ponds. However fishes are maintained in tanks and cages in case of intensive system and are totally dependent on provisional nutritionally complete diets produced in dry, semi-moist, or moist forms. Diets fed to fish are subject to leaching of nutrients while they remain in the water column or at the bottom of the culture system. Dried feeds are formulated using steam or cold compression technique for pelleting.

Different shapes and sized pellets are formed which shows different buoyancies for fishes with different floating levels. For example, catfish, salmon, and shrimp require floating, slow-sinking, or fast-sinking feeds, respectively because of their different preferred feeding habits in the water column. For salmonids and marine fishes extrusion technology is widely used to produce cold water feeds. Extruded feed contains high energy contents based on high levels of lipid (20\%-40\% of the diet). Feed efficiency for fishes is based upon their distribution and amount of feed to be fed depends upon factors like percentage of body weight and water temperature. Young fish require feed at a greater percentage of their body weight per day $(>5 \%)$ than older fish. Demand or ad libitum feeding is commonly used in hatcheries where demand feeders dispense small quantities of feed when activated by the fish.

\section{Nutrient requirements of fish}

Nutrient requirement for fishes and animals are not very different as fishes too thrive nutrients including amino acids, fatty acids, vitamins, minerals, and energy-yielding macronutrients (protein, lipid, and carbohydrate). Nutrients are required for physiological needs of growing and reproductive brood stock. With increasing population and depleted aquatic reservoirs the popularity for intensive and extensive fish rearing has greatly increased. Despite considerable advances reported over the past 5 decades, the quantitative requirements for all essential nutrients for most farmed fish species are not well established.

Nutrient requirement containing 40 specific nutrients with their quantitative nutrient requirements have been very well formulated for rainbow trout, Pacific salmon, channel catfish, tilapia, and common carp, while partial nutrient requirements have been established more recently for numerous other fish species (NRC 1993, Halver et al.,). Minimum requirements established can promote growth without any deficiency symptoms however additional amount of nutrients will increase reserves present in muscles. Although the minimum nutrient requirements established promote growth and prevent deficiency signs, higher intakes of vitamins, minerals, amino acids, and essential fatty acids increase buildup of their reserves in the tissues. However continued intake of certain nutrients in excess amounts leads to saturation of various coenzymes. It has also been found that certain fat-soluble vitamins (eg, vitamin A) and trace elements (eg, copper, selenium) can be toxic when given in excess. Deficiencies or excesses of each of the major dietary components effects largely through their effects on host defense mechanisms. Nutritional deficiencies can predispose fishes to various infections by 
affecting their skin and mucus integrity, changes in composition of tissue and body fluids and by reducing mucus secretions. However, with anorexia being a common symptom of nearly all nutrient deficiencies (NRC 1993).

Particle size is closely related to feed intake and the correct feed particle size induces a positive behavioral response. Feed particles must be sufficiently small to be ingested, while being large enough to be consumed without expending too much energy in the process.

\section{Macronutrients}

Protein forms one of the most important component of fish diet as they require a wellbalanced amino acid profile which can be provided from plant or animal sources. Deficiency in protein can lead to decreased growth and tissue development however excessive protein can lead to increased nitrogenous waste excretion which can lead to increased economic losses as protein is the most expensive part of the fish nutrition. Most herbivorous and omnivorous fish require $25 \%$ to $35 \%$ protein in their diet but carnivorous species require higher levels of protein ranging from $40 \%$ to $55 \%$ of diet (NRC 1993).This difference can be easily explained as carnivorous fishes uses proteins as an energy source as compared to carbohydrates used by herbivorous/ omnivorous fishes. The efficient use of dietary protein in these fish is also attributable to the mechanism by which ammonia, produced by deaminated protein, is excreted by way of the gills with limited expenditure of energy. Dietary protein requirements are influenced by both energy density of the diet and the ratio of energy to protein in the diet. Ten amino acids, namely arginine, histidine, isoleucine, leucine, lysine, methionine, phenylalanine, threonine, tryptophan, and valine, are considered indispensable(essential) for most fish species studied to date. Among the dispensable (nonessential)amino acids that commonly make up protein, two are particularly important for their ability to partially replace or spare indispensable amino acids. It has been observed that in fishes, requirement of phenylalanine can be spared by tyrosine upto $50 \%$ and cysteine can replace upto $50 \%$ of methionine requirement (sulfur containing amino acid). Carbohydrate requirement has not been demonstrated in fish, though lack of carbohydrates leads to excessive catabolism of proteins and lipids. Lipids supply essential fatty acids (EFAs) and energy in the diet of fish and the EFA requirement of most fish can only be met by supplying the long-chain unsaturated fattyacids of linolenic (18:3n-3) and linoleic (18:2 n-6) series. Salmonid and marine fish seem to have limited abilityto chain elongate and desaturate 18:3 n-3 and $18: 2 \mathrm{n}-6$ to meet their requirement, unlike many freshwater fish that have been shown to meet their requirements for these essential fatty acids (Bell et al., 1998).

\section{Micronutrients}

Fish have unique physiologic mechanisms to absorb and retain minerals from their diets and from the surrounding water (Lall SP 2002). Though the requirements of trace elements by fish is not clear yet, though trace elements are required for skeletal growth, cellular respiration, oxygen transport, immune function, and regulation of acid-base equilibrium, they are also important components of hormones, enzymes, and enzyme activators. Toxicity can occur due to excessive intake of minerals from gills therefore maintaining a fine balance between mineral deficiency and surplus is vital for aquatic organisms to maintain their homeostasis either through increased absorption or excretion. Quantitative dietary requirements have been reported for 
phosphorus, magnesium, zinc, iron, copper, manganese, iodine, and selenium for selected fish species. In particular, fresh water of moderate hardness (w50 mg/L as CaCO3) has been shown to provide fish with adequate calcium to sustain metabolic functions in the presence of low levels of dietary calcium. Limited presence of phosphorus in water makes phosphorus requirement critical as common plant ingredients as also lacks phosphorus availability.

\section{Use of Micro algal nutrients}

With over exploitation of fishes and increasing demand a great decrease in availability of fish meal for aquaculture has been observed. Thus making alternative protein sources for aquaculture a necessity. A lot of work has been done over the period of time and micro alga has proved to be a very good protein source which could partially or wholly replace the fish meal from fish diet.

Partial or complete replacement of fish meal has remained a topic of concern and a huge amount of work has been done for same in different fish species, like, salmon, rainbow trout, chinnok salmon-Onorhynchus spp. (Steffens 1994; Stickney et al., 1996; Bureau et al., 2000), Indian major carp - Labeo rohita (Hasan et al., 1993, 1994, 1997), Java and Nile tilapia-Oryochromis spp. ( ElSayed 1998), India major carp-Cirrhinus mrigala (Hasan et al., 1988) and common carp-Cyprinus carpio (Yilmaz et al., 2003) etc. In feeding trials with fish, many types of microalgae have been found to increase growth (protein accretion), feed utilization, physiological activity, stress response, starvation tolerance, disease resistance, and carcass quality (Mustafa and Nakagawa 1995). For example, when tested in fish diets, enhanced growth and improved protein digestibility was found on feeding of Spirulina (Mustafa et al., 1994), stress and disease resistance (Henson 1990; OlveraNovoa et al., 1998), improved carcass quality (Belay et al., 1996; Floreto et al., 1996), and induced early maturation thereby leading to a shorter breeding cycle and period of cultivation (Braun 1988). Regunathan and Wesley 2006 stated that microalgae can be used as caretonoid sources for shrimp brood stock and as a protein or lipid source to partially replace fish meals or fish oil in fish feeds (Patnaik et al., 2006). Recent studies have shown incorporation of Ulva meal may enhance carcass composition (Güroy et al., 2007; Azaza et al., 2008). The present group also tested a number of microalgal biomass mix as value added feed employing different algal genera like S. platensis, S. subsalsa, Phormidium valderianum, Phormidium tenue, N. ellipsosporum, N. minima, Rhizoclonium fontinale, Rhizoclonium riparium, Spirogyra sp., Enteromorpha intestinalis, U. lactuca for Prawn, Rohu, Tilapia and Gold fish (Khatoon et al., 2009, 2010a, b; Sen Roy et al., 2011; Mukherjee et al., 2011).T

\section{Feed conversion efficiency}

Nutrition forms $70 \%$ of the total cost of animal or fish production thus making feed efficiencyan important parameter for a successful business (Craig et al., 2017). Feed conversion ratio is considered as one of the most important parameter in intensive rearing. Feed conversion ratio is calculated as the weight of the feed fed to the fish divided by the weight of fish growth. For example, if fish are fed 20 pounds of feed and then exhibit a 10 -pound weight gain, the FCR is $20 / 10=2$. FCR above 1.5 is considered to be good growth parameter for most of the species, however fishes like tilapia, Trout and salmon tend to have lower FCR values ranging from 0.9 to 1.3. Reciprocal of the feed conversion ratio (1/FCR) is also known as feed efficiency. In the example above, the $\mathrm{FE}$ is $10 / 20=50$ percent. Therefore, if fish are fed 
24 pounds of feed and exhibit an 8-pound weight gain, the $\mathrm{FE}=8 / 24=30$ percent. An FE greater than 50 percent is generally considered acceptable. In addition to growth, some of the energy in feed is used by the fish for metabolic and digestive processing, respiration, nerve impulses, salt balance, swimming, and other living activities. Feed conversion ratios will vary among species, sizes, and activity levels of fish, environmental parameters, and the culture system used (Craig et al., 2017).

\section{Managing fish waste}

Excessive fish wastes can lead to water contamination, reduced dissolved oxygen, increased B.O.D and increased bacterial load in water. Fish wastes increases with overfeeding which can lead to huge amount of economic loss, making fish waste an important economic indicator. Usually, fish should be fed only the amount of feed that they can consume quickly (in less than five to 10 minutes). As a good general rule of thumb is to feed the fish about 80 percent of the amount of feed they want for satiation. However the needed amount of feed is fed only twice a month after regular cycle of providing $80 \%$ of feed (Craig et al., 2017). Even following the above technique there is some amount of feed which remains uneaten and gets totally wasted. On an average around $5 \%$ of feed remains uneaten, and out of 100 units of feed fed about 10-155 of feed is released as solid waste and $30-35 \%$ of feed is released as liquid waste. Of the remaining feed, about 25 units are used for growth and another 25 units are used for metabolism (heat energy for life processes). However these numbers may vary greatly with species, sizes, activity, water temperature, and other environmental conditions.

Table.1 FAO, 2018

\begin{tabular}{|l|l|l|l|l|l|l|}
\hline Year & $\mathbf{2 0 1 1}$ & $\mathbf{2 0 1 2}$ & $\mathbf{2 0 1 3}$ & $\mathbf{2 0 1 4}$ & $\mathbf{2 0 1 5}$ & $\mathbf{2 0 1 6}$ \\
\hline Total Capture & 92.2 & 89.2 & 90.6 & 91.2 & 92.7 & 90.9 \\
\hline Marine capture & 23.2 & 24.4 & 25.4 & 26.8 & 27.5 & 28.7 \\
\hline Inland capture & 38.6 & 42 & 44.8 & 46.9 & 48.6 & 51.4 \\
\hline Total aquaculture & 61.8 & 66.4 & 70.2 & 73.7 & 76.1 & 80.0 \\
\hline $\begin{array}{l}\text { Total arld } \\
\text { fisheries }\end{array}$ & 154 & 156 & 160.7 & 164.9 & 168.7 & 170.9 \\
\hline $\begin{array}{l}\text { aquaculture } \\
\text { Human }\end{array}$ & 130 & 136.4 & 140.1 & 144.8 & 148.4 & 151.2 \\
\hline $\begin{array}{l}\text { consumption } \\
\text { Non-food use }\end{array}$ & 24 & 19.6 & 20.6 & 20 & 20.3 & 19.7 \\
\hline $\begin{array}{l}\text { Per capta apparent } \\
\text { consumption (kg) }\end{array}$ & 18.5 & 19.2 & 19.5 & 19.9 & 20.2 & 20.3 \\
\hline
\end{tabular}




\section{Supplementation of carbonic anhydrase}

Though the use of carbohydrase enzymes has not been as nearly as common in aquatic species, despite their promising effects in improving nutrient digestibility by hydrolyzing non-starch polysaccharides present in plant feedstuffs. Supplementation of exogenous carbohydrases to plant-based fish diets should improve nutrient digestibility and reduce nutrient excretion. On the other hand, the effects of exogenous carbohydrases on fish performance are still unclear due to the difficulty in cross-study comparisons. Overall, based on the information gathered in this review, it is clear that research on exogenous carbohydrase supplementation in aquaculture nutrition is not extensive. According to promising results and opportunities found in other non-ruminant animals, and favorable effects found in aquaculture species studied to date, it may be significant to increase research on this subject because it could be a useful tool to improve and sustain commercial aquaculture. (Castilo et al., 2015)

\section{Nanotechnology}

Nanosciences and nanotechnologies are highly promising and rapidly progressing disciplines in research and industrial innovation. Nano sciences has helped food related streams in many ways like smart packaging, nanosensors for pathogen detection or registration of storage conditions, nano-formulations of agrochemicals, nanoencapsulation / nanodelivery of food ingredients. In the same way aquaculture can be revolutionized using the same technique as it can help in detection of diseases and enhancing the ability of fish to rapidly absorb drugs such as hormones, vaccines and nutrite feeding, disease control, and bio-fouling control processes are being re-engineered to get the maximum benefit from nanotechnology. It has been proposed that nanoparticles can increase absorption of trace elements instead of being excreted without usage. Adding other mineral nutrients to the regular fish diet at the nanoscale level might also have a tremendous impact not only on growth but also on the overall health of the fish physiology. It has been propose that the use of nanomaterials in recycling process, the waste by-products from seafood processing plant scan enhance the feed for farm-raised fish. Nano-bio-bag recycling unified filter water purification equipment shall be inoculated in the water can help very effectively degrade fish, shrimp, shellfish, crabs, sea cucumbers and ammonia metabolites. Nano-water stone: can block, the internal water bacteria and keep the water clean to control pollution. Nano technology can help in reducing B.O.D of the water and reduce the nitrite and nitrate waste of the water. Nano silver ion antimicrobial coating nano-composite coatings, is the ideal fish pond green wall paint and these are now introducing in Japan and South Korea.Nanoparticles can be used in aquaculture as a vaccine delivery agent and promises better immunity to the fishes as compared to traditional vaccinations. However, there are concerns that the benefits associated with distribution of nanoparticles may also be accompanied with risks to the environment and health. Chitosan is used to wrap the vaccine and deliver it to fish using nano encapsulation technology. Nanoencapsulated vaccines against the bacterium Listonella anguillarum can be introduced in Asian Carp.However it has been observed that engineered nano particles can cause oxidative damage to DNA, but adverse health effects have not been observed. It is obvious that the potential health risks associated with exposure to engineered ENPs are now a major international concern, yet almost nothing is known on fate and 
biological uptake of engineered nanoparticles in the aquatic environment. Furthermore, almost all studies in recent decade have been focused on the raw engineered nanoparticles, rather than the forms entering in the environment.

In conclusion, reliable estimates of nutrient requirements have been established for major cultured fish species. These estimates are rather similar among species whose natural feeding habbits and environmental requirements are comparable. Aquatic environment for aquaculture is an important part and that can be maintained by our recent technique - the nanotechnology. Within this nano vision, a revolution is inevitably occurring in science and technology, based on the recently developed ability to measure, manipulate and organize matter on the nanoscale 1 to 100 billionth of a meter. Article provides a general overview of the wide variety of nano-materials and technologies in fish culture that offer significant promising role for water recovery. It is quite evident from the foregoing discussion that nanomaterials have enormous potential to provide innovative solutions for proper or sustainable aquaculture. However, for their successful implementation in aquaculture, as commercially viable technologies, one needs to carry out a thorough study on the engineering aspects, environmental issues, scalability and cost analysis.

\section{References}

Azaza, M. S., Mensi, F., Ksouri, J., Dhraief, M. N., Brini, B., Abdelmouleh, A. and Kra1em.M. M. 2008. Growth of Nile tilapia (Oreochromis niloticus L.) fed with diets containing graded levels of green algae Ulva meal (Ulva rigida) reared in geothermal waters of southern Tunisia. Journal of Applied
Ichthyology 24: 202-207.

Belay, A., Kato, T. and Ota.Y. 1996. Spirulina (Arthrospira); Potential application as an animal feed supplement. Journal of Applied Phycology 8: 303-311

Bell, J. G. 1998. Current aspects of lipid nutrition in fish farming. In: Black KD, Pickering AD,editors. Biology of farmed fish. Sheffield (UK): Sheffield Academic; p. 114-45.

Bhattacharyya A, Debnath, N. 2008. Nano Particles-A Futuristic Approach in Insect Population, In Proceedings on UGC Sponsored National Seminar on Recent Advances In Genetics and Molecular Biology, Biotechnology and Bioinformatics.

Bhattacharyya, A. 2009. Nanoparticles-From Drug Delivery to Insect Pest Control, 1(1): 1-7.

Boujard T, Leatherland, J. F. 1992. Demandfeeding behavioural and diel pattern activity in Oncorhynchus mykiss held under different photoperiod regimes. Journal of Fish Biology 40:535-44.

Braun, L. 1988. Spirulina: Food for the future. Aquatopics, 9th ed. Baltimore: National Agricultural Library

Bureau, D. P., Harris, A. M., Bevan,D. J., Simmons, L. A., Azevedo, P. A. and Cho, C. Y. 2000. Use of feather meals and meat and bone meals from different origins as protein sources for rainbow trout (Oncorhynchus mykiss) diets. Aquaculture 181: 281-291

Castillo, S., Gatlin, D. M. III .2015. Dietary supplementation of exogenous carbohydrase enzymes in fish nutrition: a review. Aquaculture 435: 286-292

Craig, S., Helfrich, L. A., Kuhn, D. and Schwarz, M. H. 2017. Understanding fish nutrition, feeds and feeding.

Daan, S. 1981. Adaptive daily strategies inbehavior. In:Aschoff J, editor. 
Handbook of behavioral neurobiology 4, biological rhythms. New York: Plenum Press; p. 275-98.

El-Sayed, A.F.M. 1998. Total replacement of fish meal with animal protein sources in Nile tilapia, Oreochromis niloticus (L.) feeds. Aquaculture Research 29: $275-280$

FAO. 2005a. FAO/General Fisheries Commission for the Mediterranean/ International Commission for the Conservation of Atlantic Tunas. Report of the third meeting of the Ad Hoc GFCM/ICCAT Working Group on Sustainable Bluefin Tuna Farming/ Fattening Practices in the Mediterranean. Rome, 16-18 March 2005. FAO Fisheries Report No. 779. Rome. 108 pp.

FAO. 2007. Fish stat Plus: universal software for fishery statistical time series. Aquaculture production: quantities 1950-2005; Aquaculture production: values 1984-2005; Capture production: 1950-2005; Commodities production and trade: 1950-2004; Total production: 1970-2005, Vers. 2.30. FAO Fisheries Department, Fishery Information, Data and Statistics Unit. (available at: www.fao.org/fi/statis t/FISOFT/FISHPLUS.asp)

FAO. 2018. The state of world fisheries and aquaculture meeting the sustainable development goals. "Fishery and Aquaculture Country Profiles: India". Food and Agriculture Organization of the United Nations. 2011.

Floreto, E. A. T., Teshima, S. and Koshio, S. 1996. The effects of seaweed diets on the lipid and fatty acids of the Japanese disc abalone Haliotis discus hannai. Fisheries Science 62: 582-588

Gu"roy, B. K., Tekinay, A. A., Cirik, S., Gu"roy, D. and Sanver, F. 2007. Effects of Ulva rigida or Cystoseira barbata meals as a feed additive on growth performance, feed utilization, and body composition in Nile tilapia, Oreochromis niloticus. Turkish Journal of Veterinary and Animal Sciences 31: 91-97

Halver, J. E., Hardy, R. W. 2002. Fish nutrition. San Diego (CA): Academic Press; p. 824.

Hasan, M. R., and Das, P. M. 1993. A Preliminary study on the use of poultry offal meal as dietary protein source for the fingerlings of Indian major carp, Laboe rohita (Hamilton). In Fish nutrition practise, ed. S.J. Kaushik, and P. Luquet, 793-801. Paris: Institut National de la Recheche Agronomique. Hasan, M.R., M.S. Haq, R.M. Das, and G. Mowlah. 1997. Evaluation of poultry feather meal as a dietary protein source for Indian major carp, Labeo rohita Fry. Aquaculture 151: 47-54

Hasan, M. R., Roy, P. K. and Akand, A. M. 1994. Evaluation of leucaena leaf meal as dietary protein source for Indian major carp, Labeo rohita fingerling. In Fish nutrition research in Asia, 6th ed, ed. S.S. De Silva, 69-76. Manila: Asian Fisheries Society

Hasan, M. R., Roy, P. K., Shaheen, N. and Mowlah, G. 1988. Evaluation of leucaena leaf meal as dietary protein source for the fingerling of Indian major carp, Cirrhinus mrigala (Hamilton) Bangladesh. Journal of Aquaculture 10: 69-82

India's Seafood Export at all-time High in 2016-17 :MPEDA". Press Information Bureau, Government of India, Ministry of Commerce \& Industry. 7 June 2017. Retrieved 25 July 2018.

Khatoon N, Chaudhuri, A., Sen Roy, S., Kundu, N., Mukherjee, S., Mazumdar, D., Homechaudhuri, S. and Pal. R. 2010. Algae as feed supplement in fish 
nutrition. Journal of Botanical Society of Bengal 64(2): 85-93.

Khatoon, N., Chattopadhyay, P., Mukhopadhyay, A., Mukhopadhyay, M. and Pal, R. 2009. Algal diet in prawn aquaculture. Fishing Chimes 28(10/11): 44-47.

Khatoon, N., Sengupta, P., Homechaudhuri, S. and Pal, R. 2010. Evaluation of algae based feed in Gold fish (Carassius auratus) nutrition. Proceedings of Zoological Society 63(2): 109-114.

Lall, S.P.2002. Minerals. In: Halver JE, Hardy RW, editors. Fish nutrition. San Diego (CA): Academic Press; p. 260308.

Madrid, J. A., Boujard, T., Sanchez-Vazquez, F. J. 2001. Feeding rhythms. In: Houlihan D, Boujard T, Jobling M, editors. Food intake in fish. Oxford (UK): Blackwell Science Ltd; p. 189215.

Mukherjee, S., Parial, D., Khatoon, N., Chaudhuri, A., Sen Roy, S., Homechaudhuri, S. and Pal. R. 2011. Effect of formulated algae based diet on growth performance of Labeo rohita Hamilton. Journal of Algal Biomass Utilisation 2(4): 1-9

Mustafa, G. M. and Nakagawa, H. 1995. A review: Dietary benefits of algae as an additive in fish feed. Israeli Journal of Aquaculture Bamidgeh 47: 155-162. Mustafa, M.G., T. Umino, and H. Nakagawa. 1994. The effect of spirulina feeding on muscle protein deposition in red seabream, Pagrus major. Journal of Applied Icthyology 10: $141-145$.

Myhr, A. I. and Myskja, B. K. 2011. Precaution or Integrated Responsibility Approach to Nanovaccines in Fish Farming? A Critical Appraisal of the UNESCO Precautionary Principle. Nanoethics 5:
73-86.

National Research Council. Nutrient requirements of fish. Washington, DC: National Academy Press; 1993. p. 114.

Olvera-Novoa, M. A., Daminguez-Cen, L.G., Olivera-Castillo, L., Carlos, A. and Martinez-palacios. 1998. Effect of the use of the micro algae Spirulina maxima as fish meal replacement in diets for tilapia, Oreachromis mossambicus (Peters) fry. Aquaculture Research 29: 709-715.

Patnaik, S., Samocha, T. M., Davis, D. A., Bullis, R. A. and Browdy, C. L. 2006. The use of algal meals as highly unsaturated fatty acid sources in practical diets designed for Litopenaeus vannamei. Aquaculture Nutrition 12: 395-401.

Radhakrishna R "Food and Nutrition Security" in Kirit S. Parikh and R Radhakrishnas (eds) India Development Report, Oxford University Press, 2002.

Rajeshkumar, S., Venkatesan, C., Sarathi, M., Sarathbabu, V.J., Thomas Basha, K. A., and Hameed, A. S. S. 2009. Oral delivery of DNA construct using chitosan nanoparticles to protect the shrimp from white spot syndrome virus (WSSV), Fish and Shellfish Immunology, 26: 429-437

Rather, M. A., Sharma, R., Aklakur, M., Ahmad, S., Kumar, N., Khan, M., Ramya, V.L. 2011. Nanotechnology: A Novel Tool for Aquaculture and Fisheries Development. A Prospective Mini-Review. Fisheries and Aquaculture Journal: FAJ-16: 1-5.

Regunathan, C. and Wesley. S. G. 2006. Pigment deficiency correction in shrimp broodstock using Spirulina as a carotenoid source. Aquaculture Nutrition 12(6): 425-432.

Sen Roy, S., Chaudhuri, A., Mukherjee, S., 
Homechaudhuri, S. and Pal. R. 2011. Composite algal supplementation in nutrition of Oreochromis mossambicus. Journal of Algal Biomass Utilisation 2(1): 10-20.

Steffens, W. 1994. Replacing fish meal with poultry by-product meal in diets for rainbow trout, Oncorhynchus mykiss. Aquaculture 124: 27-34.

Stickney, R. R., Hardy, R. W., Koch, K., Harrold, R., Seawright, D. and Massee, K. C. 1996. The effects of substituting selected oilseed protein concentrates for fish meal in rainbow trout Oncorhynchus mykiss diets. Journal of World Aquaculture Society 27: 57-63.

Tacon, A. G. J., Hasan, M. R. and Subasinghe, R. P. 2006. Use of fishery resources as feed inputs for aquaculture development: trends and policy implications. FAO Fisheries Circular No. 1018. Rome, FAO. 99 pp.

Walker, P. J. 2004. Disease Emergence and Food Security: Global Impact of Pathogens on Sustainable Aquaculture Production. In: Fish, Aquaculture and Food Security, Sustaining Fish as a Food Supply. A conference conducted by the ATSE Crawford Fund Parliament House; pp.45-52.

World Bank Entering the 21st Century; World Development Report 1999/2000, Published by Oxford University Press, Inc, 200 Madison Avenue, New York, NY, 10016, 1999.

Yilmaz, M., Gumas, A., Yilmaz, S. and Polat, N. 2003. Aged based food preferences of common carp (Cyprinus carpio L., 1758) inhabiting fish lakes in the Bafra District of Samsun Province (Lakes Tath and Gici). Turkish Journal of Veterinary and Animal Sciences 4: 971-978.

\section{How to cite this article:}

Prabhjot Kaur Sidhu and Anant Simran Singh. 2020. Feeding of Different Categories of Fish, their Nutritional Requirements and Implication of Various Techniques in Fish Culture - A Review. Int.J.Curr.Microbiol.App.Sci. 9(01): 2438-2448. doi: https://doi.org/10.20546/ijcmas.2020.901.278 